\title{
EXPLORING ALUMNI VALUATION OF AN UNDERGRADUATE LEADERSHIP PROGRAM
}

\section{Abstract}

Limited research exists that assesses the transfer of leadership learning from an undergraduate leadership program into alumni work environments. This study explored alumni' valuation of an undergraduate leadership program by gaining an understanding of what leadership learning and leadership behaviors transferred into work environments. The participants were alumni that graduated from the same university in the southeastern United States, and while enrolled completed a four-year, co-curricular leadership program. Eight participant alumni engaged in semi-structured interviews as well as completed the Leadership Practices Inventory. The findings indicated that specific leadership learning did effectively transfer to work environments, and program alumni were frequently engaged in the Five Practices of Exemplary Leadership at work to some degree. When developing leadership programs, practitioners may consider incorporating similar programmatic attributes and leadership learning deemed valuable by program alumni.

\section{Introduction}

The purpose of this study was to explore alumni' valuation of an undergraduate leadership program by gaining an understanding of what leadership learning and behaviors associated with the Five Practices of Exemplary Leadership have transferred into the work environment (Kouzes \& Posner, 2014). Employing the following two research questions, we sought to better understand the perceived value of an undergraduate leadership program for alumni in their professional career. First, what leadership learning effectively transfers into the work environments of program alumni? Second, how frequently do alumni who completed an undergraduate leadership program engage in The Five Practices of Exemplary Leadership?

According to the National Association of Colleges and
Employers 2016 Job Outlook Survey, 80\% of the 201 employer respondents desired leadership skills to be evident on the resumes of new college graduates, and leadership skills was the highest sought attribute of college graduates. This supports the expectation on higher education to produce graduates who are prepared to be leaders, and is likely why "many college mission statements contain commitments to develop citizen leaders or prepare students for professional and community responsibilities..." (Council for the Advancement of Standards [CAS] in Higher Education, 2012, p. 447). At the end of the 1980s over 600 institutions included leadership courses, and in the late 1990s over 800 collegiate undergraduate leadership programs were in existence (CAS, 2012). The International Leadership Association's program directory currently shows there are over 1,500 programs in the United States across multiple 
disciplines that grant either a certificate or some type of leadership related degree to postsecondary students (2020).

This proliferation of leadership programming must also be coupled with quality assessment as Guthrie and Jenkins (2018) poignantly stated, "The important work of leadership education begins and ends with assessment" (p. 146). Numerous examples exist of leadership educators and researchers engaging in important assessments of leadership learning occurring on college campuses (Campbell, Smith, Dugan, \& Komives, 2012; Chesnut \& Tran-Johnson, 2013; Dugan \& Komives, 2010; Foremen \& Retallick, 2013; Foli, Braswell, Kirkpatrick, \& Lim, 2014; Gallagher, Marshall, Pories, \& Daughtey, 2014). While much of this research is centered around student development, very little research explores to what extent alumni utilize this leadership learning in their work environment after graduation. Assessing the usage of leadership learning after graduation will allow leadership educators to emphasize the lifelong, career-applicability of leadership learning taking place in their programs or courses.

\section{Literature Review}

An extensive review of the literature was conducted and will transition from the presentation of the practices of exemplary leadership as the conceptual framework to on campus student leadership development and programming, and conclude with the transfer of leadership behaviors, with the latter being the focus of our research questions.

The Five Practices of Exemplary Leadership. The Five Practices of Exemplary Leadership were generated through interviews with thousands of leaders about their personal best leadership experiences (Kouzes \& Posner, 2014) and provided the conceptual framework for this study. The practices include:
- Model the Way: This practice is typified by a leader who sets the example for his or her followers. Leaders should clarify their values, affirm the values of the group, and align their behaviors with these deeply held beliefs.

- Inspire a Shared Vision: This practice involves imagining and communicating a better, more exciting future for a group or organization. The leader casts a common vision that taps into the aspirations of the group, while bringing excitement to heightened, future possibilities.

- Challenge the Process: Leaders should look outside of the known information the group possesses to discover better ways of doing things. Willing to leave the status quo behind, leaders engaged in challenge the process are not content with doing things the way they have always been done. This practice involves advancing the group through taking risks and finding incremental steps to success.

- Enable Others to Act: Leaders understand that they cannot be successful doing the work alone. They must build effective teams by developing relationships and trust. Encouraging collaboration, the leader seeks to empower and improve others while giving followers the autonomy to do their work.

- Encourage the Heart: Encourage the heart is typified by the celebration of success, while paying homage to the groups' deeply held beliefs. The leader shows appreciation to individuals who deserve recognition and understands the group needs encouragement in 
order to continue pressing forward.

On Campus Student Leadership Development and Programming. A longitudinal study that included 2,855 students provided baseline insight that undergraduates can increase their usage of leadership behaviors on campus (Posner, Crawford \& Denniston-Stewart, 2015). The participants completed the Student Leadership Practices Inventory (S-LPI), which measures the frequency of engagement in the Five Practices of Exemplary Leadership, in their first and third years of college. Findings showed significant increase in four of the five practices from year-one to year-three. Dugan and Komives (2007) conducted an extensive landmark study on leadership development of undergraduates with over 50,000 students at 52 campuses. This Multi-Institutional Study of Leadership (MSL) included a questionnaire that measured leadership values in the Social Change Model (SCM) through the Socially Responsible Leadership Scale (SRLS), and also probed students' experiences on campuses. The SCM leadership values included: consciousness of self, congruence, commitment, collaboration, common purpose, controversy with civility, citizenship, and change. The study identified six experiences on college campuses that affect the leadership development of students including socio-cultural discussions, mentoring, campus involvement, service, student leadership roles, and leadership programming (Dugan \& Komives, 2007).

Holding student leadership positions on college campuses has been linked with increased usage of the five practices of exemplary leadership (Burbank, Odom, \& Sandlin, 2015; Gallagher et al., 2014; Patterson, 2012). Engagement in organizational leadership experiences has been significantly correlated with higher scores in four of the five leadership practices, and lower scores were found in those students who did not have leadership roles (Gallagher et al., 2014). Students who held three or more leadership positions scored higher on most of the practices as compared to students who held only one position. In an undergraduate leadership course, students responded to an end-of-course reflective prompt about their changes in leadership behaviors, and one of the emergent themes showed that participation in extracurricular activities such as student organizations led to positive changes in leadership behaviors (Burbank et al., 2015).

Officers of an honorary professional association focused on education were able to describe 18 different learned leadership skills and verbalized increased leadership confidence (Bond \& Sterrett, 2014). Interviews with student leaders explored key developmental events in the lives of college students and the leadership lessons they learned within these experiences (Sessa, Morgan, Kalenderli, \& Hammond, 2014). In this study, participants holding their first leadership position in college accounted for $8.9 \%$ of the 180 key leadership development events identified, and the expansion of responsibilities in a position or taking on a higher leadership position accounted for $8.4 \%$ of the key events. Both of these key event categories were in the top five among the 13 identified and thus, this affirmed the importance of holding leadership and advancing in leadership positions on campus.

In a seminal study, Posner (2009) compared the changes in the five practices for students who did or did not participate in specific leadership training. The study utilized a t-test comparison of S-LPI scores for seniors who completed leadership training through a business major (treatment group) and seniors who did not complete this training within other majors. The treatment group had significantly higher usage of four leadership practices including: Inspire a Shared Vision, Challenge the Process, Enable Others to Act, and Encourage the Heart (Posner, 2009). Students who participated in a year-long, co-curricular leadership program for pharmacy students had an increased desire to obtain leadership roles, felt better prepared for leadership positions, and could link their leadership learning with specific program aspects (Chesnut \& Tran-Johnson, 2013).

Service was also a significant predictor on SCM leadership values (Dugan \& Komives, 2010), and additional studies support the role of service and 
service-learning in undergraduate leadership development (Burbank et al., 2015; Foli et al., 2014). Buschlen and Warner (2014) conducted a qualitative study that included five students and a faculty advisor who repaired homes on a service trip, and the participants expressed transformational learning that could be tied to the SCM leadership values. Another study utilized a pre-test and post-test with the S-LPI, and included 65 students in a management course that implemented a public health fair and significant gains were found for all five practices due to this service-learning experience (Foli et al., 2014).

Pedagogy within leadership programs and coursework is an important consideration for leadership educators. Through 62 interviews with multiple stakeholders from four high-quality leadership programs, 16 attributes were identified in three clusters that are found in these leadership programs (Eich, 2008). This first cluster included the following attributes: students from diverse backgrounds that challenge each other, formation of smaller group to enhance learning, and accessible leadership educators. The next cluster centered on experiential learning, and the attributes consisted of group work on projects, service, and leadership retreats. These experiences were enhanced through intentional reflection, and leadership self-assessment tools. The final cluster revealed the best programs utilized evidence-based practices, are founded in research, and continually develop through assessment (Eich, 2008).

White and Guthrie (2016) analyzed journal entries and conducted 14 interviews with students who completed leadership coursework and determined that the following practices enriched leadership learning: fostering a reflective culture, collective reflection through discussion, and instructors who practice reflection. Additional studies also bolster the importance of reflection as a teaching strategy in leadership education (Haber-Curran \& Tillapaugh, 2013; Odom, 2015). Studies involving actionoriented or experiential attributes such as kayaking trips, disaster relief, volunteering off campus, and executing public health fairs have produced forms of leadership development gains for students (Boettcher \& Gansemar-Topf, 2015; Buschlen \& Warner, 2014; Foli et al., 2014; Strawn, McKim, \& Velez, 2017). Finally, Fritz and Guthrie (2017) examined the importance of classroom dynamics as they interviewed 15 students who were enrolled in or had taken a leadership course. Small classroom size, diversity among majors, and having quality faculty were found to be valuable in leadership courses.

Transfer of Leadership Behaviors. Much of the scholarship involving the transfer of learning from leadership programs or training into work environments is centered on programs developed for working professionals. For example, alumni participants of a leadership development program designed for professional women believed the experience increased their leadership efficacy and reported being promoted after the program (Brue \& Brue, 2016). Similarly, assessment of a leadership program designed for eight county human service organizations showed $21 \%$ of the participants had been promoted a year after program completion (Coloma, Gibson, \& Packard, 2012). Participants reported using 10 of the 15 leadership content areas at work. Finally, assessment of the National Clinic Leadership Development Program in Ireland revealed that after the program, managers observed new leadership behaviors and attitudes of the 36 participating nurses (Patton et al., 2013).

More specifically, a study exploring the transfer of leadership learning from higher education to the work environments of alumni noted alumni of the military medical school believed they were appropriately prepared by the school for their leadership role and could identify specific experiences at the institution that enhanced their leadership development (Dong et al., 2012). In a study with 134 former fraternity presidents, and 10 years after holding this position almost all reported this experience positively influenced their leadership development, while $80 \%$ were supervisors at work (Kelley, 2008).

In a parallel study, leadership program alumni at a liberal arts college expressed having more self- 
awareness and could leverage these insights in a way that gave them increased confidence as a leader (Soesbe, 2012). The program continued to have a positive impact in their current context, and experiential attributes of the program significantly enhanced their leadership development. Additionally, a recent study gathered survey responses from 27 students, and 103 alumni of an undergraduate leadership minor and found that alumni believed the program made them more competitive in the job market and rated the incorporation of internships and quality instructors as most important (Mitchell \& Daugherty, 2019). The researchers stated that "more research is needed to determine how, and in what ways, leadership education is impacting students' leadership skills and abilities in their careers" (Mitchell \& Daugherty, 2019, p. 142). These studies indicated that leadership learning and behaviors could transfer from leadership programming into the work environment as well leadership learning at institutions of higher education continue to be relevant for alumni in a future work environment. However, limited research shows this same transfer from undergraduate leadership programming to the professional environment and thus, this study seeks to address this gap in the literature.

\section{Methods}

Research Design. A convergent embedded mixed methods design was utilized to explore the perceived value alumni placed on an undergraduate leadership program by gaining an understanding of what leadership learning and behaviors have transferred into their work environment. Quantitative data was nested in a primarily qualitative design (Leavy, 2017), and this primary data type was guided by basic qualitative research (Merriam \& Tisdell, 2016). This design included semi-structured interviews with eight alumni of the Empower Leaders program, as well as completion of the Leadership Practices Inventory (LPI), which measures frequency of using The Five Practices of Exemplary Leadership (Kouzes \& Posner, 2014).
Empower Leaders Program. The Empower Leaders program, under pseudonym to protect participant confidentiality, was a four-year, co-curricular leadership program situated at a large university in the southeastern United States. The program focused on enabling students to develop as leaders on campus and to provide the career-applicable skills sought by future employers. The program included multiple learning objectives framed around the following areas: self-leadership, leading in teams, community and organizational leadership, and leadership legacy. The program requirements included completing non-credit leadership courses, serving in on-campus leadership positions, attending workshops, attending a leadership conference, peer leadership coaching, completing 125 service hours, participating in an alternative break trip, and a selfinitiated leadership legacy project intended to have a positive community impact. Program alumni completed either three or four non-credit leadership courses depending on when they joined the program. Each of the courses included some portion of The Five Practices of Exemplary Leadership (Kouzes \& Posner, 2014), and below is a description of the courses as aligned to student learning outcomes:

- LEAD 101 - Leading Yourself: A significant portion of the course involved the exploration of personal values and activating values within the practices of Model the Way and Encourage the Heart. Finally, the course also included modules on ethical leadership, personality type, and leadership styles.

- LEAD 102 - Leading in Teams: The course began with a focus on group dynamics. Students discovered their individual strengths through an assessment and examined how to use them on a team. An emphasis was placed on using team member's diverse strengths to be a highly effective team. Finally, the course included the practices of Enable 
Others to Act and Inspire a Shared Vision.

- LEAD 103 - Leading Change: This course focused on learning to lead positive change in communities or organizations, and students explored organizational and community culture as well as the role of power dynamics in leadership. A module covered intent versus impact, and Challenge the Process was incorporated in the course.

- LEAD 104 - Professional Development Seminar: This course was taken in conjunction with an internship or job and focused on using emotional information effectively in the workplace. Students completed an assessment to better understand their personal emotional intelligence, and the scores were utilized to help students increase their emotional intelligence in identified areas of development.

Instrumentation. We collected quantitative data through the LPI, which measures the frequency with which individuals engage in The Five Practices of Exemplary Leadership (Posner, 2016). A small effect size below .10 has been shown between respondent categories of self and observer for the five practices (Posner, 2016). This indicated that self-reported LPI and observer LPI scores were consistent. Finally, the LPI has shown internal reliability through a reliability coefficient (Cronbach's alpha) above .80 for each of the five practices (Posner, 2016). Strategies were employed to enhance trustworthiness including triangulation, reflexivity, and member checking (Creswell \& Poth, 2018). Data were triangulated between individual interviews and also included triangulation between interviews and leadership program information (e.g., syllabi, learning objectives, program requirements). Credibility was enhanced through corroboration of both qualitative and quantitative data. For member checking purposes, each participant received an email soliciting feedback on the themes, theme description, and supporting quotations from their respective interview. Finally, the primary researcher engaged in reflexive journaling immediately following each interview.

Sampling and Recruitment. The expenses for this research study were grant funded by the Graduate Student Professional Development Fund at Georgia Southern University. Participants were former students who met the following criteria: employed at least part-time and had the technological capability to engage in a web-based video interview which led to the identification of 17 eligible participants. We recruited eight participants by applying additional criteria focused on diversifying the sample that included: graduation date, undergraduate major gender, and race.

Participants. The participants, who had completed all requirements of the Empower Leaders program, included two men and six women, with an age range of 23-28. Participants had a unique program of study while in college and were recent graduates. Three participants worked for a county government, two worked for non-profit organizations, and two others worked in education. The participants were highly engaged in campus life while in college, involved in service, and held from three to seven student leadership positions.

Data Collection. Participants gave informed consent and then received an email link to the 30-item LPI, which was housed within the online LPI proprietary platform. Using a convergent design, the data collected in this first stage did not inform the next stage of data collection. In the second stage of data collection, participants were interviewed virtually through a web-based video application in a one-hour, semi-structured interview. Prior to the interview, the researcher provided the list of program requirements completed by the participant to serve as a reflection tool during the interview.

Data Analysis. Creswell and Poth's (2018) data analysis spiral served as an overarching guide while integrating specific coding and analysis techniques 
from Saldaña (2009). All interviews were transcribed and the transcripts were later compared to interview recordings to verify accuracy. Pseudonyms were given to protect the participant's identity and transcripts were imported into NVivo 10 for analysis. We began data analysis by reading the entirety of each transcript while making notations in the margins on printed copies of each transcript before using software. Analytic memos were written in NVivo 10 throughout the coding process as a means to reflect on ideas, code choices, and potential themes. During the first cycle of coding the researchers employed specific coding methods including structural, initial, and evaluation coding (Saldaña, 2009). As multiple transcripts were analyzed, a codebook was generated that included the following details: the code, code definition, and description of when to use the code (Saldaña, 2009). In almost all cases, instances of applying leadership learning at work were each coded around specific learning objectives found in the program and leadership courses. Coding was also connected to the five practices (Kouzes \& Posner, 2014). The second cycle method of pattern coding was utilized to group first cycle codes into meta-codes (Saldaña, 2009). These identified pattern codes were used in the development of descriptions of major themes.

The quantitative data were analyzed through descriptive statistics. The scoring was done by adding together the frequency scale responses from the behavior statements tied to each individual practice. The frequency scale for the instrument was 1-to-10 and there are six statements tied to each practice. This means there was a maximum score of 60 for each practice and a minimum score of six. Once respondent scores were calculated for each practice, means and standard deviations were computed for comparing to available normative data as well as qualitative data collected in this study.

\section{Findings}

RQ 1: What leadership learning effectively transfers into the work environments of program alumni? Two large clusters of applied leadership learning emerged including leading others and leading-self. The leading others cluster included the following themes: collaboration, leveraging differences, communication, diversity awareness, and negotiating conflict. The leading-self cluster included the following themes: strengths awareness, emotional intelligence (EI) awareness, and leadership confidence. At the start of each interview participants created their own pseudonyms, but these pseudonyms could not be paired with individual participant profiles in order to maintain confidentiality. The eight participants generated the following pseudonyms: Britney, Karis, Lola, Olivia, Reese, Sarah, Thomas, and Will. These names will be utilized throughout the findings to enhance flow and to honor the participants' wishes to use the pseudonym they created for themselves.

Leading Others. The leading others cluster of themes provided alumni with the competencies and leadership learning to effectively collaborate with others in their work environments. This learning occurred in the leadership classes and through other experiential components such as alternative break trips, service, and student leadership positions. Will captured the general essence of this cluster when he said, "for me it was learning how to better work with people and how to talk to people."

Collaboration. Alumni learned the general ability to collaborate with others in Empower Leaders, and they apply this skill in their work environment. Reese succinctly captured this theme. "As a [professional position] you have to collaborate. Those collaborative skills that I learned were very, very helpful." Britney best captured the essence of transferring the learned capacity to collaborate into the work environment. She stated, "So, collaboration-wise, so in the [leadership] classes, learning how to work with others and seeing that, of course, translate to alternative breaks, but then seeing it translate to my current job." Here Britney 
described learning about collaboration in leadership classes, getting the opportunity to apply this learning through an experiential element of the program, and then applying this skill in her work environment.

Leveraging differences. Alumni learned to leverage differences on a team and have applied this skill at work. This leadership learning includes effectively working with people who are different on a team or seeing differences on a team as an asset to be leveraged. These differences included strengths, weaknesses, leadership styles, and personality types. Olivia referenced the rationale for leveraging differences noting, "They wanna do individual work. Overall, I know that's not what's productive. And, what's really gonna make the best product is multiple perspectives." Lola best captured this theme by stating, “...their personality types can be different, and essentially learning that that's okay," and "...everybody has something that they can bring to the table."

Olivia echoed this sentiment: But, everyone's different. They're not gonna take warm, fuzzy hugs. Some folks want things cut and dry. And, others are more logical. And, they don't wanna talk about the feelings and emotional sides of issues. I remember that class in particular referencing it back over time.

Communication. Alumni acquired the ability to communicate in various settings through experiences tied to the program and applied this skill in their work environment. This included verbal communication, listening, or presentation skills. Lola connected communication with listening as she stated, "... you have to know how to communicate and also with that communication you have to know how to listen and listen to the needs of the people that you're leading." Thomas believed he honed listening skills through experiences from peer coaching. "I just remembered part of the aspect of coaching and leadership is not having more the wisdom but having listening skills to be ready." Sarah believed her learned presentation skills helped her advance at work. "I would say the presentation skills and stuff that has encouraged me. I guess I just didn't realize that so many people just didn't like to present, but it's kind of helped me get ahead at my work..." In this statement Sarah recalled presenting her legacy project to a large audience and transferred this experience into her work environment.

Diversity awareness. Alumni gained an awareness of working with diverse people, with differing backgrounds, from experiences tied to the program and apply this awareness in their work environments. This included awareness surrounding race, gender, age, different cultures, income, nationality, disabilities, gender sexual minority identity or other factors. Sarah connected this awareness to her work environment from learning she garnered during an alternative break trip. "So, knowing how to interact with different populations, which is super impactful with my job right now because I am going [to unfamiliar locations] and I'll be working with different cultures, different viewpoints." Olivia best captured the essence of utilizing learned diversity awareness in her work environment when she stated:

I was a [specific student leadership position] for three years. That's huge. And, it really even helps me still today in my job because as a [specific job title], I'm working with [different] groups all the time. You've got diverse groups of people, 
diverse income, race, age.

Olivia believed she gained diversity awareness in a specific student leadership position, and she continues to utilize this awareness in her work environment.

Negotiating conflict. Alumni learned skills surrounding conflict negotiation or about conflict-styles through experiences tied to the program and have applied this learning in their work environments. Olivia referenced learning about negotiating conflict in class, then through experiences in a student leadership position, and finally applying this leadership learning at work. Referring to class she said, "I remember Conflict Styles and [Collaborative Leadership course]," and she later described experiences in a student leadership position as "some intense stuff for interpersonal conflicts." Finally, she applied this leadership learning at work:

And, a lot of it, you are dealing with interpersonal conflicts as well because a lot of it is kind of someone being the squeaky wheel at a [specific type of meeting]. Or, you're trying to balance these public values that people may have issues with about security or freedom kind of matching up together and having to deal with working with the community but being more of a conduit for that group... I think [my specific student leadership position] was huge in that aspect. I still think about it all the time.

Olivia directly ties her learning experience in a specific student leadership position to the work she is currently engaged with as a professional. Reese best captured the essence of applying learned conflict negation in her work environment. She noted:

That's what I do all the time, reconciling different viewpoints, which I started learning in my leadership roles. But in Empower Leaders that's something that I do a lot. A lot of times [specific professional roles] don't agree with [other specific professional role], [specific roles] don't agree with the [specific population], and [my specific position] fills that unifying role. We all have to make a decision and it has to be a team decision. That's the biggest way I'm applying it now.

She connected this learning generally to the program, but also to her student leadership positions she held as an undergraduate. Table 1 below provides a summary of the evidence supporting the five themes associated with the leading others cluster including: collaboration, leveraging differences, communication, diversity awareness, and negotiating conflict. 
Table 1.

Responses Typifying Themes Found in the Leading Others Cluster

\begin{tabular}{|c|c|}
\hline Theme & Response \\
\hline Collaboration & $\begin{array}{l}\text { As a [specific professional position] you have to collaborate. Those } \\
\text { collaborative skills that I learned were very, very helpful. }\end{array}$ \\
\hline Collaboration & $\begin{array}{l}\text { So, collaboration-wise, so in the [leadership] classes, learning how to work } \\
\text { with others and seeing that, of course, translate to alternative breaks, but } \\
\text { then seeing it translate to my current job. }\end{array}$ \\
\hline $\begin{array}{l}\text { Leveraging } \\
\text { Differences }\end{array}$ & $\begin{array}{l}\text { So, I think that is probably the main take away. If everybody is different, } \\
\text { but everybody has something that they can bring to the table. }\end{array}$ \\
\hline $\begin{array}{l}\text { Leveraging } \\
\text { Differences }\end{array}$ & $\begin{array}{l}\text { Overall, I know that's not what's productive. And, what's really gonna } \\
\text { make the best product is multiple perspectives }\end{array}$ \\
\hline Communication & $\begin{array}{l}\text { For me, I think it's like my communication skills. So, learning some of that, } \\
\text { again, when I was at Empower Leaders. }\end{array}$ \\
\hline Communication & $\begin{array}{l}\text { I would say the presentation skills and stuff that has encouraged me. I } \\
\text { guess I just didn't realize that so many people just didn't like to present, } \\
\text { but it's kind of helped me get ahead at my work... }\end{array}$ \\
\hline Diversity Awareness & $\begin{array}{l}\text { And, it really even helps me still today in my job because as a [specific } \\
\text { professional position], I'm working with [specific] groups all the time. } \\
\text { You've got diverse groups of people, diverse income, race, age. }\end{array}$ \\
\hline Diversity Awareness & $\begin{array}{l}\text { When thinking about diversity and inclusion, I think about when I'm } \\
\text { working with [specific group], the different perspectives that could affect } \\
\text { them. }\end{array}$ \\
\hline Negotiating Conflict & $\begin{array}{l}\text { That's what I do all the time, reconciling different viewpoints, which I } \\
\text { started learning in my leadership roles. }\end{array}$ \\
\hline Negotiating Conflict & $\begin{array}{l}\text {...when someone disagrees in public in the meeting, telling them what I } \\
\text { want after, maybe don't have all of that conflict and chaos take place in } \\
\text { the meeting. So, all of that I use all the time. }\end{array}$ \\
\hline
\end{tabular}

Leading-Self. The leading-self cluster provided alumni self-awareness and an internal capacity to lead in their work environment. Britney captured the general essence surrounding the type of learning associated with this cluster stating, "So, I think a lot of what Empower Leaders did was teach me about myself and what I'm capable of doing..." and Karis echoed this sentiment stating, "I learned a lot about myself through those courses." Lola connected this self-discovery to leadership.

Well, it emphasized the importance of knowing yourself and how once you know yourself and you know your leadership style, you can figure out which - what things you need to improve on and what things you naturally do well, so when you are in a leadership position you kinda know what to look out for.

The leading-self cluster included the following themes: strengths awareness, emotional intelligence (EI) awareness, and leadership confidence.

Strengths awareness. Alumni gained an awareness of their own personal strengths 
through experiences tied to the program and have applied this learning in their work environments. Much of this awareness derived from learning about their individual talent themes through taking a specific assessment in the Collaborative Leadership course. Sarah referenced the assessment as she affirmed that she continued to utilize her identified strengths from the program. "So, StrengthsQuest is something I've carried with me throughout." Thomas described how the program encouraged the continued application of strengths awareness beyond the program:

'Yeah, you now know your strengths. You now know your weaknesses. You know this and that. What does it mean? How can you build on this?' Not just, 'Oh, I'm a WOOer. Okay, how do you use your WOO? How do you use your other strengths?'

In this statement Thomas described a specific strength found in the assessment, and how he was encouraged in Empower Leaders to utilize this strength in other contexts. When asked, "What components of the Empower Leaders Program provide the most value for you today in the workplace?" Will immediately referenced his strengths stating, "I love the leadership inventories. I love StrengthsQuest." He also was able to recall each of his top five strengths from the assessment, and his self-awareness of his ability to build relationships. Lola best captured the essence of learning and applying strengths awareness in her work environment. "In Empower Leaders I think I remember taking an assessment - strength quiz, I think it was and I remember one of my strengths being inclusion or being inclusive. And I do use that all the time."

$\begin{array}{lll}\text { Emotional } & \text { intelligence } & \text { awareness. } \\ \text { Alumni } & \text { have applied } & \text { emotional }\end{array}$

intelligence (EI) learning from the program at work or an awareness of their own emotional intelligence from the program has value in their work environment. Much of this awareness derived from learning about their own El through taking a specific assessment in the Professional Development Seminar course in Empower Leaders. Referencing the El assessment, Reese stated, "I loved EQI and I learned so much about myself and about emotional intelligence..." and Thomas also appreciated the assessment stating, "EQI taught a lot of the soft skills that you need." Thomas further expounded on the El self-awareness he gained. "So, that's why I was like, 'I'm really bad at empathy.' That's the one thing I always remember, and I remember all the activities..." Later in the interview he stated, "I've certainly gotten better at my weak points with EQI," which showed his continued awareness and application of El. Reese believed her El learning from the program made her more effective as a young professional as she noted:

I found when I was a [specific professional position] people would always tell me "You don't [do your job] like a first year [specific position]." I would sit back and think, "Why is that? What's making them say that? What am I doing differently?" They would say that I had really good rapport with [specific population]. I really brought it back to EQI and the things I learned in that.

Leadership confidence. The program gave alumni additional confidence to lead, and this confidence was often gained during the experiential components of the program. Sarah believed she grew in confidence after she failed to advocate for her point of view during one of her first alternative break trips. "And it was my 
first alternative break trip, so I think if it was like my sixth one - like I saw myself grow - I was more confident to confront them." In a similar experience, Will gained confidence as an alternative break trip leader. "I think one example I think about clearly is gaining confidence for me is one year I went to [specific state] and - when we got there - the trip that we had planned completely changed..." Will later described this confidence transferring into his work environment. He stated, "I would say currently now with that confidence, I'm not afraid to be direct and honest with people and to get my point across in the appropriate ways with different populations." Lola summarized her new-found confidence from the program stating, "And it wasn't until then - until I was in the Empower Leaders Program that I realized I could be a leader." Finally, Karis best captured the essence of applying increased leadership confidence in her work environment.

Just right off the bat, I felt like just Empower Leaders gave me the tools, and the social support, and the resources that I needed to be more than I thought that I could be, and that was really helpful in giving me the confidence to go for jobs like this where I'm now the youngest person on staff by multiple years, and I'm leading our biggest volunteer base for [specific organization] of 4,000 people.

Table 2 below provides a summary of the evidence supporting the three themes associated with the leading-self cluster including: strengths awareness, El awareness, and leadership confidence.

Table 2.

Responses Typifying Themes Found in the Leading-Self Cluster

\begin{tabular}{ll}
\hline \multicolumn{1}{c}{ Theme } & \multicolumn{1}{c}{ Response } \\
\hline Strengths Awareness & $\begin{array}{l}\text { I remember one of my strengths being inclusion or being inclusive. And I } \\
\text { do use that all the time... I think it plays into my kind of democratic way } \\
\text { of leading, of wanting everybody's voice to be heard. }\end{array}$ \\
Strengths Awareness & $\begin{array}{l}\text { What does it mean? How can you build on this?' Not just, 'Oh, I'm a } \\
\text { WOOer.' 'Okay, how do you use your WOO? How do you use your other } \\
\text { strengths? }\end{array}$ \\
El Awareness & $\begin{array}{l}\text { At one point, I even contacted [Home College Staff Member] when I was } \\
\text { [doing my specific job]. I was like 'Thank you so much for EQI because it } \\
\text { really did help me.' } \\
\text { El Awareness }\end{array}$ \\
$\begin{array}{l}\text { So, that was the first time I had learned about emotional intelligence } \\
\text { instead of IQ I guess, so that I still use it to this day... }\end{array}$ \\
$\begin{array}{l}\text { Lever happened before I was in Empower Leaders because it built the } \\
\text { confidence that I needed in myself to become - to be a leader. }\end{array}$ \\
$\begin{array}{l}\text { Confidence } \\
\text { Leadership }\end{array}$ \\
$\begin{array}{l}\text { Just right off the bat, I felt like just Empower Leaders gave me the tools, } \\
\text { and the social support, and the resources that I needed to be more than I } \\
\text { thought that I could be, and that was really helpful in giving me the } \\
\text { confidence to go for jobs like this where I'm now the youngest person on } \\
\text { staff... }\end{array}$ \\
\hline
\end{tabular}


RQ 2: How frequently do alumni who completed an undergraduate leadership program engage in The Five Practices of Exemplary Leadership? Collectively, the qualitative data and quantitative data revealed that the participants frequently engaged in the five practices at work to some degree. The alumni discussed specific instances when they utilized the five practices at work, and some tied this usage to behaviors learned while in the
Empower Leaders program. These qualitative data were corroborated by the quantitative data. Table 3 below represents a summary of the qualitative and quantitative data together as well as a comparison to available normative data using a similar age range to participants.

Table 3.

Qualitative and Quantitative Data Tied to The Five Practices of Exemplary Leadership.

\begin{tabular}{|c|c|c|c|}
\hline Practice & $\begin{array}{c}\text { QUAN } \\
\text { Result } \\
\text { Participant } \\
\text { Mean }\end{array}$ & $\begin{array}{c}\text { QUAN } \\
\text { Comparison } \\
\text { Normative } \\
\text { Data }\end{array}$ & $\begin{array}{l}\text { QUAL Result } \\
\text { Participant Response }\end{array}$ \\
\hline $\begin{array}{l}\text { Model } \\
\text { (SD) }\end{array}$ & $\begin{array}{c}47.125 \\
(5.75)\end{array}$ & $\begin{array}{c}44.72 \\
(7.799)\end{array}$ & $\begin{array}{l}\text { "I always go back - especially in my current job - it's all } \\
\text { about the values I bring to the workplace." } \\
\text { "So, definitely lead by example because you have to } \\
\text { show the people that you're leading that you're willing } \\
\text { to do it and that's kind of how I see in my job too." }\end{array}$ \\
\hline $\begin{array}{l}\text { Inspire } \\
\text { (SD) }\end{array}$ & $\begin{array}{c}39.75 \\
(11.99)\end{array}$ & $\begin{array}{c}41.21 \\
(10.043)\end{array}$ & $\begin{array}{l}\text { "...being able to pull people in on a common vision." } \\
\text { "So much is creating a vision, creating community, } \\
\text { building consensus. That's what I do all the time..." }\end{array}$ \\
\hline $\begin{array}{l}\text { Challenge } \\
\text { (SD) }\end{array}$ & $\begin{array}{l}47.875 \\
(5.46)\end{array}$ & $\begin{array}{c}43.1 \\
(8.477)\end{array}$ & $\begin{array}{l}\text { "...it's educating myself by asking the questions, by } \\
\text { researching, by placing myself strategically around the } \\
\text { community to be able to engage and learn." } \\
\text { "I changed it to electronic [specific process]. We were } \\
\text { doing it by paper, which is so manual. So, I convinced } \\
\text { our area to do it in electronic form." }\end{array}$ \\
\hline $\begin{array}{l}\text { Enable } \\
\text { (SD) }\end{array}$ & $\begin{array}{l}49.25 \\
(8.19)\end{array}$ & $\begin{array}{c}49 \\
(6.475)\end{array}$ & $\begin{array}{l}\text { "So, you have to go to the people that things will affect, } \\
\text { and so just being able to work across programs or } \\
\text { disciplines and collaborate with a lot of people to get } \\
\text { your work done." } \\
\text { "I like to get everybody's perspective and then make a } \\
\text { decision and I feel that once you have the buy-in from } \\
\text { everybody that decision's a lot easier to implement." }\end{array}$ \\
\hline $\begin{array}{l}\text { Encourage } \\
\text { (SD) }\end{array}$ & $\begin{array}{l}46.375 \\
(5.66)\end{array}$ & $\begin{array}{c}44.09 \\
(9.502)\end{array}$ & $\begin{array}{l}\text { "Encouraging [specific population]. 'Yes, I know it's } \\
\text { discouraging to hear that your [specific person] has an } \\
\text { intellectual disability. I know that the future may seem } \\
\text { limited but it's not.' They have these strengths." } \\
\text { "...but you learn to point out the positives and } \\
\text { encourage the group." }\end{array}$ \\
\hline
\end{tabular}

Note. $\mathrm{N}=8$ participants; $\mathrm{N}=45,936$ normative data (24-32 age); 60 = highest possible score 
The scores in the second column above represent the average score for the eight participants in each of The Five Practices of Exemplary Leadership. Enable Others to Act represented the highest score among the alumni with a score of 49.25/60, while Inspire a Shared Vision represented the lowest score of $39.75 / 60$. Interestingly, Enable Others to Act was most prominently found in the qualitative data as well. It is important to note that one participant scored much lower than the other participants in all five practices, especially for Inspire a Shared Vision (13/60), which significantly altered the participants' average scores.

The scores in the third column in Table 3 represents LPI normative data that included over 45,000 leader scores from an age range of 24-32, which is like the range found among the participants in this study. Barry Posner provided information from the LPI normative database directly to the researcher (personal communication, November 30, 2018). The participants' average scores were higher than the normative data scores for Model the Way, Challenge the Process, and Encourage the Heart with the largest difference found in Challenge the Process. Enable Others to Act contained a negligible difference, and the participants' average score was lower than the normative data score for Inspire a Shared Vision. The participants scored higher or the same on four of the five practices when compared to the normative data. The fourth column in Table 3 represents a brief summary of the qualitative data which corroborated that Empower Leaders alumni do engage in the five practices in their work environments. The participants scored higher or the same on four of the five practices when compared to the normative data. The fourth column in Table 3 represents a brief summary of the qualitative data which corroborated that Empower Leaders alumni do engage in the five practices in their work environments.

\section{Limitations}

This study is limited in generalizability as it explored the leadership development of alumni of a specific leadership program. Additional experiential factors after graduation could have contributed to the leadership development of participants that were not captured in this study, and these experiences postgraduation likely have an impact on participant LPI scores. The study assumes that a self-assessment tool displays an accurate picture of leadership behaviors, and that participants were truthful in their responses.

\section{Discussion}

Leadership learning has been shown to transfer from leadership development training for working professionals into the work environment (Brue \& Brue, 2016; Coloma et al., 2012; Patton et al., 2103), and some evidence exists that leadership learning can effectively transfer from a structured undergraduate leadership program into the workplace (Mitchell \& Daugherty, 2019; Soesbe, 2012). This is congruent with the findings that alumni of the Empower Leaders program were transferring leadership learning and behaviors associated with The Five Practices of Exemplary Leadership into their work environments.

In the findings, two large clusters of applied leadership learning emerged from the data and each included multiple themes. The first cluster, leading others, included the following themes: collaboration, leveraging differences, communication, diversity awareness, and negotiating conflict. Interestingly, alumni from an undergraduate leadership program at a liberal arts college expressed similar leadership learning areas: collaboration, diversity, understanding others, and communication (Soesbe, 2012). Empower Leaders were highly engaged on campus both in leadership positions and service in the community, completing hours of service as part of the program. These experiences are associated with an increased ability for undergraduates to collaborate with others (Dugan \& Komives, 2010; Strawn et al., 2017), thus it is unsurprising that this leading others cluster emerged among Empower Leaders alumni. 
The second cluster of leadership learning applied in the work environment included the following themes: strengths awareness, emotional intelligence awareness, and leadership confidence. Multiple studies surrounding undergraduate leadership learning displayed results in which students learned more about themselves or became more confident as leaders (Bond \& Sterrett, 2014; Chesnut \& TranJohnson, 2013; Eich, 2008; Soesbe, 2012). Alumni of an undergraduate leadership program at a liberal arts institution believed the strengths assessment and other similar assessments led to greater selfawareness and a better understanding of the way they lead others (Soesbe, 2012). This group also expressed having additional confidence as a leader; Empower Leaders alumni described a similar outcome. Undergraduate student leaders who served in an honorary professional organization stated that a benefit of serving in their leadership position was increased confidence as a leader (Bond \& Sterrett, 2014), and, interestingly, the Empower Leaders alumni participants held between three to seven student leadership positions each.

Findings from the quantitative and qualitative data together revealed that Empower Leaders alumni were frequently engaged in The Five Practices of Exemplary Leadership to some degree. The literature shows that collegiate experiences of engagement in formal leadership programming, holding student leadership positions, and engaging in service or service learning has been linked to leadership behavior gains specifically in the five practices (Burbank et al., 2015; Chesnut \& Tran-Johnson, 2013; Foli et al., 2014; Gallagher et al., 2014; Posner, 2009). These collegiate experiences mirror many of the experiences required by the Empower Leaders program that were described by the alumni participants, and perhaps this link may help explain the findings that Empower Leaders alumni were frequently engaged in The Five Practices of Exemplary Leadership to some degree.

\section{Conclusion and Recommendations}

Institutions of higher education continue to espouse the importance of developing future leaders, but often fail to assess the effectiveness of this leadership preparation from an alumni perspective. The alumni lens in this study provides important implications for leadership educators as well as senior level administrators in higher education when developing and implementing leadership programming. Leadership educators should consider assessing their programs by garnering alumni feedback. Furthermore, leadership educators should make an effort to maintain alumni connections and perhaps through a formalized alumni group. When developing student learning objectives, leadership educators may consider including some of the leadership learning that effectively transferred into the work environments of alumni in this study. These included collaboration, leveraging differences, communication, diversity awareness, negotiating conflict, strengths awareness, emotional intelligence (EI) awareness, and leadership confidence.

Administrators in higher education should seek to develop and fund formal leadership programming. Multiple studies in the literature show that such programs, if appropriately structured, can lead to positive leadership gains for undergraduates (Chesnut \& Tran-Johnson, 2013; Dugan \& Komives, 2007; Posner, 2009; Sessa et al., 2014). Furthermore, the findings from this study provided evidence that many alumni are likely to transfer their leadership learning into work environments from these programs. Administrators should seek to support and continue funding for existing leadership programs, while ensuring they incorporate attributes associated with high-quality leadership programs (Eich, 2009).

More research should be conducted that includes the alumni perspective on their experiences in leadership programs. Future studies with alumni may want to explore how these programs have impacted their personal lives, and engagement in the community. Additionally, this study assumed that alumni participants had an accurate picture of themselves, and future studies with alumni may seek to incorporate input from those that work with 
alumni.

Finally, the researchers predicted that alumni interviewed for this study had moved through an experiential-type of learning cycle numerous times after graduation in terms of their individual leadership learning. Thus, we recommend continued research with a lens of Experiential Learning Theory (ELT), as described by Kolb (1984), which involves the transformation of experience into learning. The experiential learning cycle has four modes including concrete experience, reflective observation, abstract conceptualization, and active experimentation. Concrete experience is the active participation in an experience without partiality, and this is followed by reflective observation, which entails reflecting on experiences while contemplating multiple perspectives. The learner then develops a working theory that integrates these reflections through the third mode of abstract conceptualization. Finally, in the active experimentation mode, these developed theories are put to use when solving problems or making decisions.

The application of ELT as a lens in this study is relevant as a unique approach as "Ideas are not fixed and immutable elements of thought but are formed and reformed through experience" (Kolb, 1984 , p. 26). In future studies, we will attempt to reach back into the memories of participants' experiences in the program, when they traveled through the experiential learning cycle, to capture these moments of learning. Additionally, we plan to explore portions of the participants' present-day experiential learning cycles and investigate whether or not participants were still actively experimenting with or applying learning from the program at work. Conceptually, the idea is to examine if prior student learning outcomes generated from learning cycles in the programmatic past were pulled into present day learning cycles. 


\section{References}

Boettcher, M. L., \& Gansemer-Topf, A. M. (2015). Examining leadership development through student leader outdoor recreation training. Recreational Sports Journal, 39, 49-58.

Bond, N., \& Sterrett, W. (2014). Developing teacher leaders through honorary professional organizations in education: Focus on the college student officers. Education, 135(1), 25-38.

Brue, K. L., \& Brue, S. A. (2016). Experiences and outcomes of a women's leadership development program: A phenomenological investigation. Journal of Leadership Education, 15(3), 75-97.

Burbank, M., Odom, S. F., \& Sandlin, M. R. (2015). A content analysis of undergraduate students' perceived reasons for changes in personal leadership behaviors. Journal of Leadership Education, 14(2) 182-197.

Buschlen, E. L., \& Warner, C. A. (2014). "We're not in Kansas anymore:" Disaster relief, social change leadership and transformation. Journal of Student Affairs Research and Practice, 51(3), 311-322.

Campbell, C. M., Smith, M., Dugan, J. P., \& Komives, S. R. (2012). Mentors and college student leadership outcomes: The importance of position and practice. Review of Higher Education, 35(4), 595-625.

Chesnut, R., \& Tran-Johnson, J. (2013). Impact of a student leadership development program. American Journal of Pharmaceutical Education, 77(10), 1-9.

Coloma, J., Gibson, C., \& Packard, T. (2012). Participant outcomes of a leadership development initiative in eight human service organizations. Administration in Social Work, 36(1), 4-22.

Council for the Advancement of Standards in Higher Education (CAS), (2012). CAS professional standards for higher education (8th ed.). Washington, DC: Author.

Creswell, J. W., \& Poth, C. N. (2018). Qualitative inquiry and research design: Choosing among five approaches (4th ed.). Thousand Oaks, CA: Sage Publications.

Dong, T., Durning, S., Gilliland, W., DeZee, K., Waechter, D., McManigie, J., \& Artino, A. R. (2012). Leadership success and the Uniformed Services University: Perspectives of flag office alumni. Military Medicine, 177(9), 61-67.

Dugan, J. P., \& Komives, S. R. (2007). Developing leadership capacity in college students: Findings from a national study. A report from the Multi-Institutional Study of Leadership. College Park, MD: National Clearinghouse for Leadership programs.

Dugan, J. P., \& Komives, S. R. (2010). Influence on college students' capacities for socially responsible leadership. Journal of College Student Development, 51(5), 525-549.

Eich, D. (2008). A grounded theory of high-quality leadership programs. Journal of Leadership \& Organizational Studies, 15(2), 176-187

Foli, K. J., Braswell, M., Kirkpatrick, J., \& Lim, E. (2014). Development of leadership behaviors in undergraduate nursing students: A service-learning approach. Nursing Education Perspectives, 35(2), 76-82. 


\section{References}

Foremen, E. A., \& Retallick, M. S. (2013). Undergraduate participation in extracurricular activities and leadership development. Journal of Leadership Education, 12(2), 56-73.

Fritz, M. R., \& Guthrie, K. L. (2017). Values clarification: Essential for leadership learning. Journal of Leadership Education, 16(1), 47-63.

Gallagher, M. L., Marshall, J. C., Pories, M. L., \& Daughety, M. (2014). Factors effecting undergraduate leadership behaviors. Journal of Leadership Education, 13(1), 46-56.

Guthrie, K. L, \& Jenkins, D. M. (2018). The role of leadership educators: Transforming learning. Charlotte, NC: Information Age Publishing Inc.

Haber-Curran, P., \& Tillapaugh, D. (2013). Leadership learning through student-centered and inquiryfocused approaches to teaching adaptive leadership. Journal of Leadership Education, 12(1), 92-116.

International Leadership Association (2017). Leadership Program Directory. Retrieved from http://www. ila-net.org/resources/LPD/.

Kelley, D. R. (2008). Leadership development through the fraternity experience and the relationship to career success after graduation. The Research Journal of the Association of Fraternity Advisors, 3(1), 1-12.

Kolb, D. A. (1984). Experiential learning: Experience as the source of learning and development. Englewood Cliffs, NJ: Prentice-Hall.

Kouzes, J. M., \& Posner, B. Z. (2014). The student leadership challenge: Five practices for becoming an exemplary leader (2nd ed.). San Francisco, CA: Jossey-Bass.

Leavy, P. (2017). Research design: Quantitative, qualitative, mixed methods, arts-based, and community based participatory research approaches. New York, NY: Guilford Press.

Merriam, S. B., \& Tisdell, E. J. (2016). Qualitative research: A guide to design and implementation. San Francisco, CA: Jossey-Bass.

Mitchell, D. T. \& Daugherty, J. (2019). Learning to lead: Perceptions of undergraduate leadership minor programs. Journal of Leadership Education, 18(1), 133-145.

National Association of Colleges and Employers (2016). Job outlook 2016: Attributes employers want to see on new college graduates' resumes. Retrieved from http://www.naceweb.org/s11182015/employerslook-for-in-new-hires.aspx

Odom, S. F. (2015). Undergraduate student perceptions of the pedagogy used in a leadership course: A qualitative examination. Journal of Leadership Education, 14(2), 17-29.

Patterson, B. (2012). Influence of student organizational leadership experiences in college students' leadership behaviors. E-Journal of Organizational Learning and Leadership, 10(1), 1-12.

Patton, D., Fealy, G., Mcnamara, M., Casey, M., Connor, T. O., Doyle, L. \& Quinlan, C. (2013). Individual-level outcomes from a national clinical leadership development programme. Contemporary Nurse, 45(1), 5663. 


\section{References}

Posner, B. Z. (2016). Investigating the reliability and validity of the leadership practices inventory. Administrative Sciences, 6(4), 1-23.

Posner, B. Z. (2009). A longitudinal study examining changes in students' leadership behavior. Journal of College Student Development, 50(5), 551-563.

Posner, B. Z., Crawford, B., \& Denniston-Stewart, R. (2015). A longitudinal study of Canadian student leadership practices. Journal of Leadership Education, 14 (2), 161-181.

Saldaña, J. (2009). The coding manual for qualitative researchers. Thousand Oaks, CA: Sage Publications.

Sessa, V. I., Morgan, B. V., Kalenderli, S., \& Hammond, R. E. (2014). Key events in student leaders' lives and lessons learned from them. Journal of Leadership Education, 13(2), 1-28.

Soesbe, W. J. (2012). Voices of lived experiences of alumni who completed an undergraduate leadership program in a small liberal arts college (Doctoral dissertation). Retrieved from lowa State University Digital Repository. (12471)

Strawn, K., McKim, A. J., \& Velez, J. J. (2017). Linking experiences and outcomes with a postsecondary leadership development program. Journal of Leadership Education, 16(1), 34-46.

White, J. V., \& Guthrie, K. L. (2016). Creating a meaningful learning environment: Reflection in leadership education. Journal of Leadership Education, 15(1), 60-75 